\title{
Determinants of Islamic Banking Performance: An Empirical Study in Indonesia
}

\author{
Taufikur Rahman ${ }^{1^{*}}$, Aprih Santoso ${ }^{2}$ \\ 'Syariah Accounting Department, IAIN Salatiga, Indonesia \\ ${ }^{2}$ Management Department, Economics Faculty, Universitas Semarang, Indonesia
}

Submitted: 26 June, 2019; Accepted: 14 March, 2020; Published: 18 March, 2020

\begin{abstract}
This study aimed to examine the effects of Capital Adequacy Ratio (CAR) and Good Corporate Governance (GCG) on Return On Asset (ROA) with Non-Performing Financing (NPF) as a moderating variable. The sample used in this study is 14 Islamic commercial banks listed on Bank Indonesia from 2014-2018. The sampling technique used in this research is purposive sampling with the type of data used in this research is panel data. To analyze the data, the researchers use a statistical test that includes classical assumption test, t-test, F-test, the coefficient of determination (R2), and Moderated Regression Analysis (MRA). The process of data analysis is using a means of IBM SPSS Statistics 23. The results of this study show that CAR has a negative and significant effect on ROA, and GCG does not have a substantial impact on ROA. This study indicates that NPF is unable to moderate the effect of CAR on ROA. However, NPF is significantly able to moderate the effect of $G C G$ on $R O A$.
\end{abstract}

Keywords: capital adequacy ratio (CAR), good corporate governance (GCG), non-performing financing $(N P F)$, return on asset (ROA).

\begin{abstract}
Abstrak
Penelitian ini bertujuan untuk menguji pengaruh rasio kecukupan modal (CAR) dan tata kelola perusahaan yang baik (GCG) terhadap pengembalian asset (ROA) dengan pembiayaan bermasalah (NPF) sebagai variabel moderasi. Sampel yang digunakan dalam penelitian ini adalah 14 bank syariah yang terdaftar di Bank Indonesia periode 2014-2018. Teknik pengambilan sampel dalam penelitian ini adalah teknik purposive sampling dengan data yang digunakan adalah data panel. Teknik analisis yang digunakan adalah uji statistik meliputi uji asumsi klasik, uji t test, F-test, koefisien determinasi (R2), dan Moderated Regression Analysis (MRA). Pengolahan data dalam penelitian ini menggunakan alat bantu IBM SPSS Statistics 23. Hasil penelitian ini menunjukkan bahwa CAR berpengaruh negatif dan signifikan terhadap ROA dan GCG tidak berpengaruh secara signifikan terhadap ROA. Penelitian ini juga menunjukkan bahwa NPF tidak mampu memoderasi pengaruh CAR terhadap ROA. Namun, NPF secara signifikan mampu memoderasi pengaruh GCG terhadap ROA.
\end{abstract}

Kata Kunci: rasio kecukupan modal, tata kelola perusahaan yang baik, pembiayaan bermasalah, pengembalian asset. 


\section{INTRODUCTION}

According to the Financial Services Authority (Otoritas Jasa Keuangan/OJK) data in 2019 , the total assets of Islamic banks in Indonesia only reach $5.85 \%$ of the total value of the entire national banking assets. The current development of the domestic Islamic banks is still far from the expectations. Several factors that delay the development of Islamic banks (including human resources) are inadequate (Hulu, 2019). Also, the lack of socialization of the bank to the public about the existence of Islamic banks.

The company's financial performance is closely related to measurement and assessment performance. Performing measurement is the qualification, efficiency, and effectiveness of the company in operating a business during the accounting period (Hanafi, 2007). According to Munawir (2012), the purpose of measuring the company's financial performance uses ROA is to know the level of liquidity, solvency, profitability, and stability. Profitability measures a company's ability to earn profits in relation to sales, total assets, and its capital (Sartono, 2001; Mai, 2006). Profitability is related to investment. Measurement of profitability can use the rate of return from the investment (return on investment-ROI), or the rate of return on assets ( $\mathrm{ROA})$.

Capital Adequacy Ratio (CAR), can be calculated using a CAR ratio in which Bank Indonesia sets a CAR of $8 \%(\mathrm{Ali}, 2006)$. The previous studies have contradictory results. So, it needs to conduct another research related to the factors affecting ROA. Pravasanti (2018), on her research, concludes that CAR has a positive and significant effect on ROA of Islamic banks. The results of Harun (2016), and Kusumastuti and Alam (2019) reach contradictive conclusions. They find that CAR does not affect profitability or ROA.

To establish a functional and resilient Islamic banking industry, it requires the implementation of good corporate governance in the commercial banks and the Islamic Sharia Business Unit, and they also have to meet the principles of sharia consumers (in line with Islamic principles) (Bank Indonesia, 2009). Several previous research claims that the application of GCG can increase the reputation and public confidence of the Islamic bank (Hartutik \& Asmita, 2016). Then, several studies done by Hisamudin and Tirta K (2012), Ghaffar (2014), and Prasojo (2015) show that GCG has a positive and significant impact on the financial performance of Islamic Banking. By the implementation of GCG, Islamic Banks' profitability is about to increase. However, the research by Permatasari and Novitasary (2014), Paul, Ebelechukwu, and Yakubu (2015), and Siswanti (2016), show that GCG does not affect the bank's performance.

The different and conflicting results require a moderated variable (Anthony \& Govindarajan, 2007). The inconsistency of the previous results might be affected by NonPerforming Financing (NPF). It can be done by strengthening or weakening the relationship (moderation) between CAR and GCG on profitability (ROA). So, this research examines the 
effect of Capital Adequacy Ratio (CAR) and Good corporate governance (GCG) on Return on Asset (ROA) with Non-Performing Financing (NPF) as moderating variables.

\section{Capital Adequacy Ratio(CAR)}

Capital Adequacy Ratio (CAR) is a capital ratio that explains the ability of banks to prepare funds for their business development purposes and anticipate the risk of loss of funds due to bank operations (Ali, 2004). In other words, the capital adequacy ratio is the bank's performance ratio to assess the level of bank capital adequacy for supporting assets that may have produce risks. Bank Indonesia determines if ROA $>1.22 \%$ is labelled as "good", 0.99 $1.22 \%$ (good enough), and $<0.77 \%$ (poor). The higher level of CAR makes the bank's ability to overcome the risk also getting higher (e.g., risky credit or productive risky assets) and the ability the bank to fund its operations. It means that the banks can provide a large contribution to banks' profitability (Kuncoro \& Suhardjono, 2002). Primadewi and Suputra (2015) conclude that capital adequacy has a positive effect on the profitability of BPD Bali. Akhtar, Ali, and Sadaqat (2011) conclude that CAR has a positive effect on the profitability of the Islamic Banks of Pakistan. Singh (2015) concludes that capital adequacy has a positive effect on the profitability of banking companies in India. Also, Saputra and Budiasih (2016) conclude that the capital adequacy of banks has a positive effect on bank profitability.

Capital adequacy will undoubtedly give effect to the profitability's enhancement of the company because the company can carry out its business operations without worrying about the risks that may arise. Merkusiwati (2007) on her research states that the high level of CAR will affect the level of profitability so that it can be a benchmark for investors and other interested parties to find whether the bank is right or not. The low level of CAR will undoubtedly decline the public's sight in banks, because of the little guarantee trust in the community. In other words, the lower the CAR grade, the more inefficient the bank will be. Also, the smaller funds of the bank will result in the lower bank's ability to maintain the risk of loss possibility, so that the bank's performance will undoubtedly decrease.

\section{Good Corporate Governance (GCG)}

Good corporate governance (GCG) in the banking industry is described as a relationship among the board of commissioners, the board of executive directors, stakeholders, and shareholders (Idroes, 2011). GCG is a set of regulations to direct, manage, and supervise the relationship between company managers and stakeholders in a company to increase the company's reputation. Companies that can improve GCG quality show an enhancement in their market valuations, while companies that have been faced GCG quality's declination seem to decrease in their market valuations (Cheung, 2011). 
GCG can create a supportive environment such as an efficient bank and alleviate financial risks. Creditors and other funders are more likely to provide finance when they feel comfortable enough with excellent corporate governance arrangements. Good corporate governance also increases organizational resilience and resilience of external shocks (Greuning \& Bratanovic, 2011). The primary focus of corporate governance mechanisms is to design effective corporate control to assure executives act in the best interest of stakeholders (Awotundun, Kehinde, \& Somoye, 2011). The implementation of good corporate governance has to maintain the company's business sustainability and maximize value for an extended period. Indonesia Financial Services Authority (OJK) believes that GCG can improve Board of Commissioners' role, Board of Directors' role, shareholder rights, material corporate transaction, disclosure and transparency, and also internal control. Therefore, these will increase investor confidence, reduce the cost of capital, and create sustainable company performance.

\section{Non-Performing Financing (NPF)}

The ratio that assesses the risky level of bank financing, whether it is clear or unclear, is Non-Performing Financing (NPF). The small proportion of NPF will result in a low level of risk from guaranteed financing by the bank, and vice versa. Based on Bank Indonesia's regulation No.13/23/PBI/2011 concerned to Implementation of Risk Management for Sharia Commercial Banks and Sharia Business Units, there are ten types of risks: (1) Return risk; (2) Complaint risk; (3) Investment risk Credit risk; (4) Reputational risk; (5) Strategic risk; (6) Operational risk; (7) Legal risk; (8) Market risk Compliance risk; (9) Liquidity risk; and (10) Credit risk.

All of these risks lead to non-performing financing. The problem of financing in a large number will affect a reduction in the bank's operating level. Then, low NPF means profitability will be high. According to the Bank Indonesia Regulation Number 14/15/PBI/2012 concerning the assessment of commercial bank asset quality article 12 number 3, credit quality is divided into: a). Current; b). Special mention; c). Sub Standard; d). Doubtful; and e). Loss. 


\section{Profitability}

The extended probability of a company generates profits from sales and investment of the firm (Weston \& Copeland, 2008). If the profitability of the firm is good, the stakeholders (creditors, suppliers, and investors) will see the extent to which the company can generate profits from sales and investment of the company. Suharli (2006) states that a good company's performance will also increase the value of the company. Profitability concerning investment connects profit with investment. Measurement is the return on investment (ROI), or the rate of return on assets (return on assets/ROA). However, an analyzed performance is ROA. The description of the size of gained net profit is the result of this ratio. It means that the decreased rate will affect net income. This analysis is used by many researchers to proxy the profitability of ROA. It is a tool that measures bank management's ability to obtain generated profits by the average of the total assets of the Bank (Almilia \& Herdinigtyas, 2005). Profitability assesses a company's ability to get benefits in its trading with sales, total assets, and its funds.

According to Kasmir (2010), profitability is a ratio to assess a company's ability to seek profits and also provide a measurement of the effectiveness of a company's management. This ratio is the efficiency of the company because of the profits generated on sales and investment income. Profitability will assess income according to the income statement with the investment book value. The profitability ratio can be compared with a rate that is equal to the ratio of other corporations in the previous year or often referred to as the average industry ratio (Tampubolon, 2005). According to Horne and Wachowicz (2012), profitability is a relationship that occurs between profit and sales; and profit with investment; they become the indication for the effectiveness of the overall company's operation. While Sutrisno (2007), the measurement tool used in profitability is ROA through a comparison of net income after tax and total assets. The application of ROA is useful because its essential to assess the effectiveness of generated profits gained by a company using company-own assets.

\section{The Effect of Capital Adequacy Ratio (CAR) and Good Corporate Governance (GCG) on Profitability (Return on Assets/ROA)}

Capital Adequacy Ratio (CAR), as one of the indicators, assesses bank's ability to cover declining assets due to bank losses and assets. This high ratio implies the financial capital of the bank's position will be better. Bank of International Settlement Standard (BIS) provides the minimum capital at $8 \%$ of risk-weighted assets (Kuncoro \& Suhardjono, 2012). In the banking business, ROA is used to measure the ability of bank management to obtain profits (profit before tax), which is resulted from the total assets from the concerned bank (SE BI No.6/23/DPNP Jakarta, May $\left.31^{\text {st }}, 2004\right)$. The result of the study from Wibowo and Syaichu (2013), Ahmad, Nafees, and Khan (2012), Schiniotakis (2012), Eljelly and Elobeed (2013), also Yusuf and Surjaatmadja (2018) state that the higher CAR, the better bank's ability to bear 
the risk of each risky productive asset or vice versa, so that CAR has a positive and significant effect on profitability (ROA). Based on those studies, the researchers formulate the first hypotheses (H1) as follows:

$\mathrm{H}_{1}$ : Capital Adequacy Ratio (CAR) has a positive and significant effect on the Profitability (ROA) of Islamic Commercial Banks in Indonesia

According to Kusima in Ristifani (2009), theoretically, good corporate governance practices can improve the company's performance and reduce the risk that may be carried out by the board with a beneficial decision. Further, good corporate governance, in general, can increase investor confidence to invest capital that impacts on financial performance. The essence of good corporate governance will economically maintain the business' continuity, profitability, and growth (Achmad, 2009). The results of studies from Hisamuddin and Tirta K (2012), Ghaffar (2014), and Prasojo (2015) state that the higher of GCG has a positive and significant impact on the financial performance of Islamic Banking. Based on the above explanations, the second hypotheses (H2) is as follows:

$\mathrm{H}_{2}$ : Good Corporate Governance (GCG) has a positive and significant effect on the Profitability (ROA) of Islamic Commercial banks in Indonesia

\section{The Role of Non-Performing Financing (NPF) as Moderating Variable on The Relationships Among Capital Adequacy Ratio (CAR), Good Corporate Governance (GCG) and Profitability (Return on Assets/ROA)}

Non-Performing Financing (NPF) illustrates the ability of bank management to manage financial problems. The higher number of NPF results in the low quality of a bank's credit. Hasibuan (2006) states that the uncertainty of returned credit causes risky lending. According to Wahyuningsih, Oemar, and Supriyanto (2015), NPL's effect comes from unsolved interest so that it influences ROA. Therefore, it empirically shows that NPF has a significant impact on the relationship between NPF and ROA. Then, the researchers formulated the third hypotheses as follows:

$\mathrm{H}_{3}$ : Non-Performing Financing (NPF) will weaken the effect of Capital Adequacy Ratio (CAR) on Profitability (ROA) of Islamic Commercial Banks in Indonesia

NPF/NPL reflects the size of the credit risk faced by the bank. Therefore, if a bank has a high Non-Performing Loan (NPL), it indicates that the bank is not professional in credit management. It is also an indication that the level of risk on the bank's lending is quite high in line with the high NPL faced by banks (Riyadi, 2006). Credit risk that resulted from NPF harms the bank's financial performance and ROA (Kusumastuti \& Alam, 2019). Thus, the impact of good corporate governance on the profitability of Islamic banks will be weak if the Islamic banks have a high NPF. So, the researchers formulate the four hypotheses as follows: 
$\mathrm{H}_{4}$ : Non-Performing Financing (NPF) will bring down the effect of Good Corporate Governance (GCG) on Profitability (ROA) of Islamic Commercial banks in Indonesia

\section{Conceptual Framework}

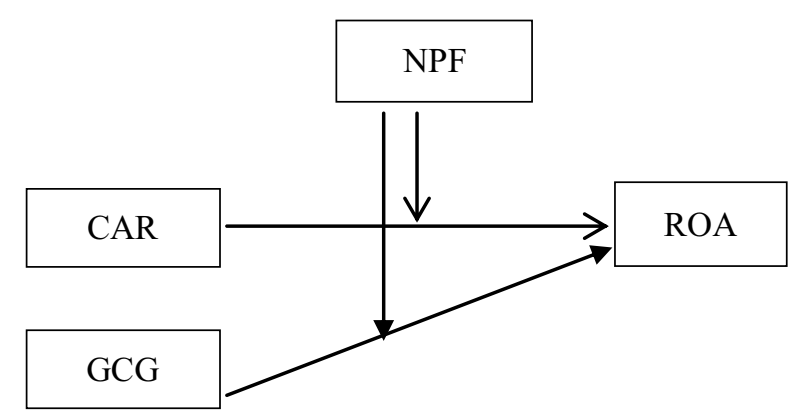

Figure 1. The Effect of CAR, GCG on ROA Moderated by NPF

\section{METHOD}

The research's form used is causal associative research with a quantitative approach. The method of collecting data in this research uses secondary data from Islamic commercial banks' financial statements (in the period 2014-2018). The data are taken through annual reports published by Bank Indonesia (BI), the Financial Services Authority (OJK), and the website of Islamic commercial banks. The samples used in this study are 14 Islamic commercial banks listed on Bank Indonesia for the period 2014-2018. The sampling technique used in this research is a purposive sampling by the criteria: (1) The Islamic commercial banks are consistently listed in Bank Indonesia for the period 2014-2018; (2) The availability of financial statements published by Islamic commercial banks from Bank Indonesia. Then, the samples are taken from 70 observations over five years. In conducting analysis, there are several forms of tests used, such as descriptive statistics analysis, determination of regression models, classic assumption tests, and interaction test or moderated regression analysis (MRA). Moreover, the processing and analysis of data use IBM SPSS Statistics 23. There are two regression equations on this research by moderating variable, as follows:

$$
\begin{aligned}
& Y=a+b 1 X 1 \ldots \ldots \ldots \ldots \ldots \ldots \ldots \ldots \ldots \ldots \ldots \ldots \ldots \\
& Y=a+b 1 X 1+b 2 X 2+b 3 X 1 X 2 . .
\end{aligned}
$$




\section{RESULTS AND DISCUSSION}

\section{Descriptive Statistics}

Table 1. Descriptive Statistic

\begin{tabular}{lccccc}
\hline & N & Minimum & Maximum & Mean & Std. Deviation \\
\hline CAR & 70 & 11.51 & 163.07 & 24.6313 & 19.96535 \\
\hline ROA & 70 & -20.00 & 12.40 & .7177 & 4.28300 \\
\hline GCG & 70 & 1.00 & 3.00 & 2.1286 & .53626 \\
\hline NPF & 70 & .00 & 4.97 & 2.3127 & 1.73069 \\
\hline Valid N (listwise) & 70 & & & & \\
\hline
\end{tabular}

Source: Secondary Processed data

Table 1 shows the descriptive statistic data; the average value (mean) of ROA is 0.717 with a minimum value -20.00 , the maximum value 12.40 , and the standard deviation value 4.28. Based on these data, it can be seen that there is a significant difference between the lowest and highest ROA values, range from -20.00 to 12.40 . This value indicates that ROA has increased.

The average value (mean) of CAR is 24.63 with a minimum amount is 11.51 , the maximum value is 163.07 , and the standard deviation value is 19.965 . These data indicate a vast difference between the lowest and highest CAR values between 11.51 and 163.07. This value shows that CAR has increased. Based on data from table 1, it can be seen that the standard deviation value is still below from mean CAR (Mean $>$ Std. Deviation). The data shows that data deviations are small, or there are no outlier data. In this study, CAR is used as a measurement of capital adequacy's level.

The average value (mean) of GCG is 2.12 , with a minimum amount of 1 , the maximum value is 3 , and the standard deviation value is 0.536 . These data indicate a significant difference between the lowest and highest GCG value, range from 1 to 3. The average value (mean) of NPF is 2.31 , with a minimum amount of 0.00 , the maximum value is 4.97 , and the standard deviation value is 1.730. Another result shows the difference between the lowest and highest NPF values, which are between 0.00 and 4.97. This value indicates that the NPF has increased. Then, from table 1, it can be seen that the amount of the standard deviation is still below the average (mean) value of NPF (Mean> Std. Deviation). The data shows that data deviations are small, or there are no outlier data. In this, study NPF is used as a measurement of non-performing financing's level, which is calculated by dividing non-performing financing from the total financing issued by the Islamic commercial banks. 


\section{Normality Test}

Table 2. Normality Test One-Sample Kolmogorov-Smirnov Test

\begin{tabular}{llr}
\hline \multirow{2}{*}{ N } & & Unstandardized Residual \\
\hline \multirow{2}{*}{ Normal Parameters } & & 70 \\
\hline \multirow{2}{*}{ Most Extreme Differences } & Mean & .0000000 \\
\cline { 2 - 3 } & Std. Deviation & 3.36383762 \\
\cline { 2 - 3 } & Absolute & .127 \\
\cline { 2 - 3 } & Positive & .127 \\
\cline { 2 - 3 } & Negative &. .103 \\
\hline Kolmogorov-Smirnov Z & & 1.064 \\
\hline Asymp. Sig. (2-tailed) & & .208 \\
\hline a. Test distribution is Normal & & \\
\hline
\end{tabular}

The normality test in this study applies the one-sample Kolmogorov-Smirnov test. The significance level used is $\alpha=0.05$. If the probability value $p \geq 0.05$, it indicates the normality's assumption is fulfilled. Moreover, the result of the normality test on table 2 shows the probability value on 0.208 . It is more than 0.05 . This means that the assumption of normality is fulfilled.

\section{Heteroscedasticity Test}

Table 3. Heteroscedasticity test

\begin{tabular}{|c|c|c|c|c|c|c|}
\hline \multicolumn{7}{|c|}{ Coefficients $^{\mathrm{a}}$} \\
\hline & & \multicolumn{2}{|c|}{$\begin{array}{l}\text { Unstandardized } \\
\text { Coefficients }\end{array}$} & $\begin{array}{l}\text { Standardized } \\
\text { Coefficients }\end{array}$ & \multirow[b]{2}{*}{$\mathrm{t}$} & \multirow[b]{2}{*}{ Sig. } \\
\hline \multicolumn{2}{|c|}{ Model } & B & Std. Error & Beta & & \\
\hline \multirow[t]{4}{*}{1} & (Constant) & 1.047 & .968 & & 1.081 & .284 \\
\hline & Ln_CAR & -.107 & .290 & -.059 & -.368 & .714 \\
\hline & Ln_GCG & .070 & .302 & .033 & .233 & .816 \\
\hline & Ln_NPF & .008 & .060 & .022 & .142 & .888 \\
\hline
\end{tabular}

a. Dependent Variable: Abresid3

The heteroscedasticity test in this study uses the Glejser test. The significance level used is $\alpha=$ 0.05 . If the probability value $\mathrm{p} \geq 0.05$ indicates that it will not affect the heteroscedasticity. The result of the heteroscedasticity test on table 3 shows the probability value of all variables in this study. It is more than 0.05 . So, it can be concluded that there is no problem of heteroscedasticity. 


\section{Multicollinearity Test}

Table 4. Multicollinearity Test

\begin{tabular}{|c|c|c|c|c|c|c|c|c|}
\hline \multicolumn{9}{|c|}{ Coefficients $^{a}$} \\
\hline \multirow{2}{*}{\multicolumn{2}{|c|}{ Model }} & \multicolumn{2}{|c|}{$\begin{array}{l}\text { Unstandardized } \\
\text { Coefficients }\end{array}$} & \multirow{2}{*}{$\begin{array}{r}\begin{array}{l}\text { Standardized } \\
\text { Coefficients }\end{array} \\
\text { Beta }\end{array}$} & \multirow{2}{*}{$\mathrm{t}$} & \multirow{2}{*}{ Sig. } & \multicolumn{2}{|c|}{$\begin{array}{c}\text { Collinearity } \\
\text { Statistics }\end{array}$} \\
\hline & & B & $\begin{array}{l}\text { Std. } \\
\text { Error }\end{array}$ & & & & Tolerance & VIF \\
\hline \multirow[t]{4}{*}{1} & (Constant) & 7.296 & 1.810 & & 4.031 & .000 & & \\
\hline & CAR & -.059 & .022 & -.273 & -2.710 & .009 & .918 & 1.090 \\
\hline & GCG & -.787 & .795 & -.099 & -.990 & .326 & .944 & 1.059 \\
\hline & NPF & -1.496 & .257 & -.604 & -5.827 & .000 & .869 & 1.151 \\
\hline
\end{tabular}

a. Dependent Variable:

ROA

Based on table 4, the VIF value of the obtained independent variable is around 1 to 10 or less than 10. It shows that there are no multicollinearity symptoms.

\section{Coefficient of Determination}

Table 5. Test Result $\mathrm{R}^{2}$ dan Adjusted $\mathrm{R}^{2}$

\begin{tabular}{lcrrr}
\hline \multicolumn{5}{c}{ Model Summary $^{\mathbf{b}}$} \\
\hline Model & $\mathrm{R}$ & $\mathrm{R}$ Square & $\begin{array}{r}\text { Adjusted R } \\
\text { Square }\end{array}$ & $\begin{array}{r}\text { Std. Error of the } \\
\text { Estimate }\end{array}$ \\
\hline 1 & $.619^{\mathrm{a}}$ & .383 & .355 & 3.43944 \\
\hline a. Predictors: (Constant), NPF, GCG, CAR & & & \\
\hline
\end{tabular}

Source: Processed Secondary data

The result of the test is 0.383 . It means that the independent variables such as CAR, NPF, GCG are able to show $38,3 \%$ variation of ROA dependent variable; meanwhile, the rest $61,7 \%$ can be explained by the other factor which is not included in the model.

\section{Hypothesis Test Results and Discussion}

Table 6. Coefficients Test Results

\begin{tabular}{|c|c|c|c|c|c|c|}
\hline \multicolumn{7}{|c|}{ Coefficients $^{a}$} \\
\hline & \multirow{2}{*}{ Model } & \multicolumn{2}{|c|}{$\begin{array}{l}\text { Unstandardized } \\
\text { Coefficients }\end{array}$} & \multirow{2}{*}{$\begin{array}{r}\text { Standardized } \\
\text { Coefficients } \\
\text { Beta }\end{array}$} & \multirow[t]{2}{*}{$\mathrm{t}$} & \multirow[t]{2}{*}{ Sig. } \\
\hline & & $\mathrm{B}$ & Std. Error & & & \\
\hline \multirow[t]{6}{*}{1} & (Constant) & 2.096 & 2.310 & & .908 & .368 \\
\hline & CAR & -.055 & .022 & -.249 & -2.452 & .017 \\
\hline & GCG & 1.583 & 1.023 & .194 & 1.548 & .127 \\
\hline & NPF & 1.718 & .966 & .678 & 1.777 & .080 \\
\hline & CAR_NPF & -.002 & .014 & -.024 & -.153 & .879 \\
\hline & GCG NPF & -1.429 & .418 & -1.388 & -3.420 & .001 \\
\hline
\end{tabular}

a. Dependent Variable: ROA

Source: Processed Secondary data 


\section{Hypotheses 1 Test:}

\section{The Effect of Capital Adequacy Ratio (CAR) on Profitability (Return on Assets/ROA)}

The results show that the regression coefficient of CAR is -0.055 with significancy level of 0.017. CAR has a significant and negative effect on Return on Assets (ROA) by $t=-2.452$. This proves that the higher CAR does not ease the bank's ability to bear the risk of each productive risk asset or vice versa, so that CAR has a negative and significant effect on profitability (Return on Assets/ROA). As a result, hypothesis 1 is not accepted. This means that the higher CAR ratio owned by the banks is the cause of a diminishing of ROA ratio.

According to the banks' theory, if the bank has CARs ranging from $8 \%$ to $14 \%$, it means that it has excellent performance because the bank could handle the risks which probably arise. However, the data show that the Islamic commercial banks in Indonesia have a very high CAR ratio. It is seen from the average CAR ratio value in table 1 (19.96535). Then, the other previous researches conducted by Almunawwaroh and Marliana (2018), Muin (2017), and Sari, Anshori, and Primasari (2018), explain that CAR has a negative and significant effect on profitability (ROA). Those data are different from research's results from Wibowo and Syaichu (2013), Ahmad, Nafees, and Khan (2012), Schiniotakis (2012), Eljelly and Elobeed (2013), and Yusuf and Surjaatmadja (2018) whom find that CAR has a positive and significant effect on profitability (Return on Assets/ROA).

\section{Hypotheses 2 Test:}

\section{The Effect of Good Corporate Governance (GCG) on Profitability (Return on Assets/ROA)}

The results show that the regression coefficient of Good Corporate Governance (GCG) is 1.583 with significancy level of 0.127 . Then, GCG does not show a significant and positive effect on ROA by $\mathrm{t}=1.548$. This proves that whether high or low of GCG of Islamic commercial banks in Indonesia have, it has no impact on the profit earned by the bank. As a result, hypotheses 2 is not accepted. This happens because of the bank's unilateral assessment, that makes the assessment result is less objective (Munawaroh \& Azwari, 2019). Moreover, the other researches which have the same finding are written by Permatasari and Novitasary (2014), Paul, et al. (2015), Siswanti (2016), Setiawan (2017), and Munawaroh and Azwari (2019), they find that GCG does not affect the return on assets. However, the result of these studies contradicted the other studies found by Hisamuddin and Tirta K (2012), Ghaffar (2014), and Prasojo (2015), which show that GCG has a positive and significant effect on the financial performance of Islamic Banking. 


\section{Hypotheses 3 Test:}

\section{The Role of Non-Performing Financing on the Relationship Between Capital Adequacy Ratio (CAR) and Return on Assets (ROA)}

The result of the hypotheses test shows that Non-Performing Financing (NPF) has no significant and negative effect on the relationship between CAR and ROA. The value of the regression coefficient of CAR variable interaction with NPF has a coefficient value of -.002 with significancy level of 0.879 (more than 0.05). This result proves that NPF is unable to moderate the relationship between CAR and ROA. NPF does not weaken the link between CAR on profitability (ROA). So, empirically NPF is unable to play the role of the moderating variable on the relationship between CAR and ROA. As a result, hypotheses 3 is not accepted. This result is in line with the researches conducted by Ganggarani and Budiasih (2014), Taufik (2017), and Yusuf and Surjaatmadja (2018). It shows that NPF cannot significantly moderate the relationship between CAR on profitability (ROA). However, the result of this study is different from the studies done by Wahyuningsih et al. (2017), and Lestari (2019), which state that the ability of NPF to moderate the relationship between CAR on profitability (ROA).

\section{Hypotheses 4 Test:}

\section{The Role of Non-Performing Financing on the Relationship Between Good Corporate Governance (GCG) and Return on Assets (ROA)}

The result of the hypotheses test shows that Good Corporate Governance (GCG) has a significant and negative effect on the relationship between GCG and ROA. The value of the regression coefficient of GCG variable interaction with NPF has a coefficient value of -1.429 with significancy level of 0.001 , less than 0.05 . This result proves that Non-Performing Financing (NPF) can moderate the relationship between GCG and ROA. This means that NPF significantly decreases the relationship between GCG and profitability (ROA). So empirically, NPF can play the role of moderating variable from the relationship between CAR and ROA. As a result, hypothesis 4 is accepted.

\section{CONCLUSIONS}

The result of this study shows that CAR, GCG, and NPF have a significant effect on ROA simultaneously. However, an independent CAR's variable has a substantial and negative impact on profitability (ROA) and GCG, and it does not have a significant and positive effect on ROA. It can be explained that when CAR has increased, it may not necessarily increase the profitability of Islamic banking in Indonesia. Therefore, this happens because the data shows that the Islamic commercial banks in Indonesia perform a high level of their CAR ratio. In fact, the banks' management has less ability to handle their risky problem. Therefore it will affect their profitability. The result of this study shows that NPF is unable to moderate the relationship between CAR and ROA. However, NPF can moderate the relationship between GCG and ROA. 


\section{REFERENCES}

Achmad, Z. (2009). Manajemen Sumber Daya Manusia, Cetakan Kedua. Jakarta: Penerbit Fajar.

Ahmad, S., Nafees, B., \& Khan, Z. A. (2012). Determinants of Profitability of Pakistani Banks: Panel Data Evidence for the Period 2001-2010. Journal of Business Studies Quarterly, 4(1), 149-165.

Akhtar, M. F., Ali, K., \& Sadaqat, S. (2011). Factors Influencing the Profitability of Islamic Banks of Pakistan. International Research Journal of Finance and Economics, 66, 125132.

Ali, M. (2006). Manajemen Risiko: Strategi Perbankan dan Dunia Usaha Menghadapi Tantangan Globalisasi Bisnis. Jakarta: Raja Grafindo Persada.

Ali, M. (2004). Asset Liability Management, Menyiasati Risiko Pasar dan Risiko Operasional dalam Perbankan. Jakarta: PT. Gramedia.

Almilia. L. S., \& Herdinigtyas, W. (2005). Analisis Rasio CAMEL terhadap Prediksi Kondisi Bermasalah pada Lembaga Perbankan Periode 2000-2002. Jurnal Akuntansi dan Keuangan, 7(2), 131-147.

Almunawwaroh. M., \& Marliana. R. (2018). Pengaruh CAR, NPF dan FDR terhadap Profitabilitas Bank Syariah di Indonesia. Amwaluna: Jurnal Ekonomi dan Keuangan Syari'ah, 2(1), 1-18. DOI: https://doi.org/10.29313/amwaluna.v2i1.3156.

Anthony, R. N., \& Govindarajan, V. (2007). Sistem Pengendalian Manajemen. Edisi Sebelas, Buku Dua, Jakarta: Salemba Empat.

Awotundun, D. A., Kehinde, J. S., \& Somoye, R. O. C. (2011). Corporate Governance and Stakeholders' Interest: A Case of Nigerian Banks. International Journal of Business and Management, 6(10), 102-112.

Cheung, A.W. K. (2011). Do Stock Investors Value Corporate Sustainability? Evidence From An Event Study. Journal of Business Ethics, 99(2), 145-165. DOI: 10.1007/s10551-0100646-3.

Eljelly, A. M. A., \& Elobeed, A. A. (2013). Performance Indicators of Banks in a Total Islamic Banking System: The Case of Sudan. International Journal of Islamic and Middle Eastern Finance and Management, 6 ( 2 ), 142 155.https://doi.org/10.1108/17538391311329833.

Ganggarani. N. W., \& Budiasih. I. G. A. N. (2014). Pengaruh Capital Adequacy Ratio dan Loan to Deposit Ratio pada Penyaluran Kredit dengan Non-Performing Loan Sebagai Variabel Pemoderasi. E-Jurnal Akuntansi, 6(2), 319-339.

Ghaffar, A. (2014). Corporate Governance and Profitability of Islamic Banks Operating in Pakistan. Interdisciplinary Journal of Contemporary Research in Business, 6(2), 320336.

Greuning, H. V., \& Bratanovic, S. B. (2011). Analisis Risiko Perbankan, Edisi 3. Jakarta: Salemba Empat.

Hanafi, M. M. (2007). Analisis Laporan Keuangan, Edisi Ketiga. Yogyakarta: UPP STIM YKPN.

Harun, U. (2016). Pengaruh Ratio-Ratio Keuangan CAR, LDR, NIM, BOPO, NPL terhadap ROA. Jurnal Riset Bisnis dan Manajemen, 4(1), 67-82.

Hartutik \& Asmita. B. (2016). The Influence of Good Corporate Governance Implementation to The Financing Quality, Efficiency and Profitability of Syariah Bank in Indonesia (Inflation as Moderating Variable), Proceeding The $2^{\text {nd }}$ International Multidisciplinary Conference, 85-96. 
Hasibuan, M. S. P. (2006). Dasar-Dasar Perbankan. Jakarta: PT. Bumi Aksara.

Hisamuddin, N., \& Tirta K, M. Y. (2012). Pengaruh Good Corporate Governance Terhadap Kinerja Keuangan Bank Umum Syariah. Jurnal Akuntansi Universitas Jember, 10(2), 109-138. DOI: https://doi.org/10.19184/jauj.v10i2.1254.

Horne, J. C. V \& Wachowicz, J. M. (2012). Prinsip-Prinsip Manajemen Keuangan (Edisi 13). Jakarta: Salemba Empat.

Hulu, N. (2019). Strategi Penegembangan Bank Syariah di Daerah Otonomi Gunungsitoli Nias. Tansiq: Jurnal manajemen dan Bisnis Islam, 2(2), 165-181.

Idroes, F. N. (2011). Manajemen Risiko Perbankan. Jakarta: PT Raja Grafindo Persada.

Kasmir. (2010). Analisis Laporan Keuangan. Jakarta: PT. Raja Grafindo Persada.

Kuncoro, M., \& Suhardjono. (2002). Manajemen Perbankan (Teori dan Aplikasi), Edisi Pertama, Yogyakarta: Penerbit BPFE.

Kuncoro. M., \& Suhardjono. (2012). Manajemen Perbankan: Teori dan Aplikasi, Edisi Kedua, Yogyakarta: Fakultas Ekonomi dan Bisnis UGM.

Kusumastuti, W, I., \& Alam, A. (2019). Analysis of Impact of CAR, BOPO, NPF on Profitability of Islamic Banks (Year 2015-2017). Journal of Islamic Economic Laws, 2(1), 30-59. DOI: https://doi.org/10.23917/jisel.v2i1.6370.

Lestari, N. L. A. (2019). Analisis Dampak Tingkat Kecukupan Modal dan Tingkat Penyaluran Kredit Terhadap Profitabilitas dengan Risiko Kredit Sebagai Variabel Pemoderasi pada Perusahaan Perbankan yang Terdaftar di Bursa Efek Indonesia Tahun 2012-2016. Jurnal Sains, Akuntansi dan Manajemen (JSAM), 1(3), 145-191. DOI: https://doi.org/10.1234/jsam.v1i3.62

Mai, M. U. (2006). Analisis Variabel-Variabel yang Mempengaruhi Struktur Modal Pada Perusahaan-Perusahaan LQ-45 di Bursa Efek Jakarta, Jurnal Ekonomika, 228-245.

Merkusiwati, N. K. L. A. (2007). Evaluasi Pengaruh CAMEL Terhadap Kinerja Perusahaan, Buletin Studi Ekonomi, 12(1).

Muin. S. A. (2017). Analisis Faktor-Faktor yang memengaruhi Rentabilitas Pada P.T. Bank Rakyat Indonesia (Persero) Tbk. Periode 2011-2016. Jurnal Economix, 5(2), 137-147.

Munawaroh, D., \& Azwari. P. C. (2019). Effect of Risk Based Bank Rating on Financial Performance of Sharia Commercial Banks. Akuntabilitas: Jurnal Ilmu Akuntansi, 12(2), 201-214. DOI: https://doi.org/10.15408/akt.v12i2.13189.

Munawir. (2012). Analisis Laporan Keuangan. Yogyakarta: Liberty.

Paul. G. D., Ebelechukwu, E. C., \& Yakubu. S. (2015). Impact of Corporate Governance on Financial Performance of Microfinance Banks in North Central Nigeria. International Journal of Humanities Social Sciences and Education, 2(1), 153-170.

Permatasari, I., \& Novitasary, R. (2014). Pengaruh Implementasi Good Corporate Governance terhadap Permodalan dan Kinerja Perbankan di Indonesia: Manajemen Risiko Sebagai Variabel Intervening. Jurnal Ekonomi Kuantitatif Terapan, 7(1), 52-59. DOI: https://doi.org/10.24843/JEKT.2014.v07.i01.p06. 
Prasojo. (2015). Pengaruh Penerapan Good Corporate Governance terhadap Kinerja Keuangan Bank Syariah. Jurnal Dinamika Akuntansi dan Bisnis, 2(1), 59-69.

Pravasanti, Y. A. (2018). Pengaruh NPF dan FDR Terhadap CAR dan Dampaknya Terhadap ROA pada Perbankan Syariah di Indonesia, Jurnal Ilmiah Ekonomi Islam, 4(3), 148159.

Primadewi, C. I. D. R., \& Suputra, I. D. G. D. (2015). Pengaruh Capital Adequacy Ratio, NonPerforming Loan dan Dana Pihak Ketiga Pada Profitabilitas. E-Jurnal Akuntansi Universitas Udayana, 13(2), 489-498.

Ristifani. (2009). Analisis Implementasi Prinsip-Prinsip Good Corporate Governance dan. Hubungannya Terhadap Kinerja PT. Bank Rakyat Indonesia (Persero) Tbk. Skripsi. Universitas Gunadarma.

Riyadi. S. (2006). Banking Assets and Liability Management. Jakarta: LPFE UI.

Saputra, I. M. H. E., \& Budiasih, I. G. A. N. (2016). Pengaruh Kecukupan Modal, Risiko Kredit, Biaya Operasional Pendapatan Operasional Terhadap Profitabilitas Bank. E-Jurnal Akuntansi, 14(3), 2363-2378.

Sari. C. P., Anshori. M. Y., \& Primasari. N. S. (2018). Impact of CAR, OCOI, NIM, NPL, and LDR on ROA (Case Study of Banks Registered in LQ45 Year 2017). Proceeding International Conference Technopreneur and Education (ICTE).

Sartono. A. (2001). Manajemen Keuangan Teori dan Aplikasi. Yogyakarta: BPFE.

Schiniotakis, N. (2012). Profitability Factors and Efficiency of Greek Banks. EuroMed Journal of Business, 7(2), 185-200. DOI: 10.1108/14502191211245606.

Setiawan. A. (2017). Analisis Pengaruh Tingkat Kesehatan Bank Terhadap Return on Asset. Jurnal Analisa Akuntansi dan Perpajakan, 1(2), 130-152. DOI: http://dx.doi.org/10.25139/jaap.v1i2.346.

Singh, A. (2015). Effect of Credit Risk Management on Private and Public Sector Banks in India. International Journal of Academic Research in Business and Social Sciences, 5(1), $97-$ 106. DOI: 10.6007/IJARBSS/v5-i1/1404.

Siswanti. I. (2016). Implementasi Good Corporate Governance pada Kinerja Bank Syariah. Jurnal Akuntansi Multiparadigma, 7(2), 307-321. D O I : http://dx.doi.org/10.18202/jamal.2016.08.7023.

Suharli, M. (2006). Studi Empiris mengenai Pengaruh Profitabilitas, Leverage, dan Harga Saham terhadap Jumlah Dividen Tunai (Studi pada Perusahaan yang Terdaftar di Bursa Efek Jakarta Periode 2002-2003). Jurnal Manajemen, Akuntansi dan Sistem Informasi, 6(2). 243-256.

Sutrisno. (2007). Manajemen Keuangan, Teori, Konsep dan Aplikasi. Jogjakarta: Konosia.

Tampubolon, M. P. (2005). Manajemen Keuangan (Finance Management): Konseptual, Problem \& Studi Kasus. Bogor: Ghalia Indonesia.

Taufik, M. (2017). Pengaruh Financing to Deposit Ratio dan Capital Adequacy Ratio terhadap Return on Asset dengan Non-Performing Financing Sebagai Variabel Moderasi Pada Bank Umum Syariah di Indonesia. At-Tawassuth: Jurnal Ekonomi Islam, 2(1), 170-190. DOI: http://dx.doi.org/10.30821/ajei.v2i1.779. 
Wahyuningsih, T., Oemar, A., \& Supriyanto, A. (2017). Pengaruh CAR, NPF, FDR, BOPO, dan GWM terhadap Laba Perusahaan (ROA) pada Bank Umum Syariah di Indonesia Periode 2010-2015. Jurnal Ilmiah Mahasiswa S1 Akuntansi Universitas Pandanaran, $3(3), 1-17$.

Weston, J. F., \& Copeland. (2008). Dasar-Dasar Manajemen Keuangan Jilid II. Jakarta: Erlangga.

Wibowo, E. S., \& Syaichu, M. (2013). Analisis Pengaruh Suku Bunga, Inflasi, CAR, BOPO, NPF Terhadap Profitabilitas Bank Syariah. Diponegoro Journal of Management, 2 (2), 10-19.

Yusuf, M., \& Surjaatmadja. S. (2018). Analysis of Financial Performance on Profitability with Non-Performance Financing as Variable Moderation (Study at Sharia Commercial Bank in Indonesia Period 2012-2016). International Journal of Economics and Financial Issues, 8(4), 126-132.

Regulations:

Bank Indonesia Regulation Number 13/23/PBI/2011 concerning Application of Risk Management for Sharia Commercial Banks and Sharia Business Units.

Bank Indonesia Regulation Number 14/15/PBI/2012 concerning Assessment of Commercial Bank Asset Quality. 